\title{
Capital Structure and Firm Performance in the Nigerian Cement Industry
}

\author{
EL-Maude, Jibreel Gambo \\ Department of Accountancy, MAUTECH Yola
}

\author{
Abdul-Rahman Ahmad \\ School of Postgraduate Studies \\ Department of Accounting, Bayero University Kano \\ Ahmad, Mohammed Musa \\ School of Preliminary Studies \\ Sule Lamido University, Kafin Hausa, Jigawa State
}

\begin{abstract}
The study examines the impact of capital structure on financial performance of firms in Nigerian cement industry. The population of the study 7 companies, a sample of 4 listed companies were selected. The research design is ex-post factor using two models to analyse the impacts of long term and short term debts on Return on Assets (ROA) and Return on Equity (ROE). The study uses balanced panel data of 20 observations from the 4 listed companies for the periods ranging from 2010-2014. Descriptive statistics, correlation and regression are used as tools of analysis. The study reveals that, there is statistically significant effect between long and short term liability on Return on Assets (ROA) and Return on Equity (ROE). The study however, concluded that the performance of companies in the cement industry is not optimized as a result of their inability to utilized debts in their capital structures. Finally, the paper recommends that, cement companies should encourage the use of long term debt in there capital structure since it has positive impact on their financial performance.
\end{abstract}

Key Words: Capital Structure, Ownership Structure, Firm Performance \& Cement Industry.

\section{INTRODUCTION}

One of the most central position theories in firm financing policy is the theory of capital structure. The capital structure of a firm is the combination of debt containing preference stock and equity; this is referred to as the firms' long term financing mix, Watson and Head (2007). Capital structure decision is a basic for any business establishment because of the need to get the most out of return to the numerous stake holders and also because of the fact that such decision has excessive impression on the firms' ability to compete in competitive atmosphere. One critical issue challenging managers today is how to decide on the mixture of debt and equity to achieve optimal capital structure that would lessen the firm's cost of capital and increases return to owners of the business. Though, firms generally have a choice as to how to mix debt and equity, managers attempt to establish a particular mixture that will get the most out of performance and the firm's market value. Such kind of mixture of debt and equity will lessen the firm's cost of capital and hence increases the firm's returns and market value is the 
ideal capital structure. Unfortunately, financial managers lack clear cut policy that can give them a guide when taking decision in piecing together optimal capital structure.

The notion of contemporary theory of capital structure is the pathway breaking contribution of Modigliani and Miller (1958) in the perfect capital market postulation. Modigliani and miller (1958) postulate that under condition of no bankruptcy cost and frictionless capital markets without taxes firm's value is independent of its capital structure. Alternatively, other school of thought holds that financing choice reveals an attempt by corporate managers to balance tax guard of higher debt beside potential huge cost of financial distress arising from under investment (Awunyo, 2012). In addition much debt can destroy firm's value by causing financial distress and under investment then too little debts can also leads to over investment and negatively affect returns particularly in large and mature firms (Barclays and Smith, 2005).The choice of capital structure and its subsequent risk experience is very vital in economic performance of every company. Hence, the choice of debt or equity ultimately results in the growth value of investment made by numerous sets of investors particularly equity investors (Watson and Head, 2007). This is essential because of the fact that equity investors have greater expectation of returns on their investment in the form of higher dividends and capital gain (Sulaiman, 2001). Any result different to this expectation will make holders of equity shares sale off their shareholding which can lead to the fall in the share price of the company. The fall in share price is an indicator to potential investors of the poor performance of the company and thereby discouraging potential investors from investing mutually in equity stock and debt.

The expansion in Nigeria's economy over the years has been followed by an accelerated growth in the country's cement industry. While the economy has risen since the country's return to democracy in 1999, with services now accounting for the modal proportion of the economy post GDP rebasing, the cement industry has recorded increase in production capacity, from c.3.28MT in 1999 to c.28.95MT in 2013 (Neneng, 2014). Over time, the Nigerian cement industry has undergone different stages of structural evolution; from complete dependence on imported cement to cater for the ever rising demand for cement in the domestic market, the industry has evolved to a more vibrant, multibillion-dollar, self-sufficient cement industry, with an expanding capacity more than sufficient to cater for domestic needs and support government's goal to diversify the nation's revenue sources, improve foreign earnings and make Nigeria a net exporter of excess cement in the medium-to long-term. The structural evolution of the industry has created improved employment prospects, eliminated the exportation of jobs meant for Nigerians to other cement producing nations hitherto renowned as exporters of massive quantities of cement into Nigeria, saved costs associated with cement importation and helped Nigeria to begin unwinding dependence on cement imports to meet local demand. Gradually, Nigeria has begun earning income from exportation of excess cement produced locally.

However, the industry is bedeviled with numerous problems of how to fund the dollar cost of the various modernization which urgently needs to be carried out, erratic power supply as companies are forced to invest an increased amount of resources in self-generation of power to keep the plant running and ownership structure as government formerly owned majority of the shares in most of the cement companies in Nigeria due to the indigenization policy of 1972. There is evidence to show that the companies that have the government has majority shareholders have consistently under performed. However, the recent development of privatization of public enterprises is resulting in ownership changes of the major producing companies (Awen, 2004). 
Many theories have been advanced to elucidate on capital structure of firms. Though, there is lack of consensus in the midst of researchers of financial management with respect to optimal capital structure. Such discrepancies in various theories are being propounded to update allimportant decision and to further make capital structure essential. As a result, capital structure decision is very vital, particularly in relation to performance of a firm in terms of profitability and value of the equity (Awunyo, 2012).In Nigeria, number of studies has been conducted to examine the determinants of capital structure and profitability. However, only few of them were specifically directed toward listed cement companies in Nigeria.

Consequent upon this, the paper seeks to examine the impact of capital structure on firm's financial performance in the Nigerian cement industry. However, this study considers Return on Equity, long term debt, short term debt and firm size for the decision and analysis of data for a period of 5 years, spanning from 2010 to 2014.

\section{LITERATURE REVIEW}

This section reviews the concepts of capital structure, firm performance and ownership structure as defined by various scholars in the field. Also, the section reviews previous studies carried out in the field of capital structure and firm performance as well as the brief on the cement industry.

\section{The Concept of Capital Structure}

Many Scholars in the field of finance have advanced quite a number of definitions as to the concept of capital structure. Nirajini and Priya (2013) define capital structure as the way in which an organization is financed a combination of long term capital (ordinary shares and reserves, preference shares, debentures, bank loans, convertible loan stock and so on) and short term liabilities such as a bank overdraft and trade creditors. According to Brockington (1990), described capital structure of a firm as the components of its sources of financing, broadly categorized as equity and debt finance. Also, Brealey and Myers (2003) define capital structure as the mix of different securities. Besides, Konchhar, (1997) as cited in Saidu (2014) viewed firms capital structure is described as the mix or combination of its financial resources available for carrying on the business and is a major determinant on how the business operates. According him financial capital is an uncertain but critical resource for all firms as a result; suppliers of the finance are to exert control over firms.

From the above definitions, it could be deduced that debt and equity form the basis of financing business activities. As debt holders exert minimum control over the company, and do not in any case determine how the business activities should be run. They are on side of the fixed rate of return and protected by contractual terms of obligations. This term determine what return they are entitling to and when is it due for payment. Equity holders, on the other way round, are the residual suitors of all the business' returns after resolving for interest on debt. They however, form the most risk bearers, having greater control virtually overall activities, decision inclusive.

\section{The Concept of Financial Performance}

There are little consensus about the best mechanism to apply for evaluating performance. Some researchers use market measures such as Tobin Q (Awunyo-Victor and Bandu, 2012; Gropp and Heider, 2009), others use accounting measures such as ROA, ROE, (Muritala, 2012; Oladeji and Olokoyo, 2014; Saidu, 2014; and Salawu, 2009) and many others use both. The three ways represent the different perspective of how to evaluate firm financial performance and theoretical implication (Hillman and Keim, 2001). As such using any of the two 
performance measures is bound by peculiar bias (MacGuire, Scheneeweis and Hill, 1986) as cited in Saidu, (2014). However, accounting measure captures the historical aspect of the firm performance, whereas market measures are forward looking and focus on the market performance. Besides market based measures are generally relevant accounting based measures commonly used by researchers (i.e Return on equity, return on capital employed and return on assets). This could be as a result of it historical antecedent measures to managers.

\section{Capital Structure and Firm performance}

Agency cost theory is based on the idea that the interests of the company's managers and its shareholders are not perfectly associated. In their seminal paper Jensen and Meckling (1976) as cited in Margaritis and Psillaki (2009), lay emphasis on the importance of the agency costs of equity arising from the separation of ownership and control of firms whereby managers tend to maximize their own utility rather than the value of the firm. Agency costs can also be present from conflicts between debt and equity investors. These conflicts ascend when there is a risk of defaulting. This risk of defaulting may form what Myers (1977) referred to as an "underinvestment" or "debt overhang" problem. In such case, debt may have a negative effect on the value of the firm. On the other hand, there may be cases where managers have enticements to take excessive risks as part of risk shifting investment strategies (see Jensen and Meckling, 1976). This leads us to Jensen's (1986) “free cash flow theory" where as stated by Jensen (1986: p. 323) "the problem is how to motivate managers to disgorge the cash rather than investing it below the cost of capital or wasting it on organizational inefficiencies." Thus high debt ratios may be used as a disciplinary device to reduce managerial cash flow waste through the threat of liquidation (Grossman and Hart, 1982) or through pressure to generate cash flows to service debt (Jensen, 1986). In these circumstances, debt will have a positive effect on the value of the firm.

But firm performance might also distress capital structure choice (see Berger and Bonaccorsi di Patti, 2006). This reverse causality effect is in essence a feature of theories linking agency costs (Jensen and Meckling, 1976; Myers, 1977; Harris and Raviv, 1990), corporate control issues (Harris and Raviv 1988), and in particular, lop-sided information (Myers and Majluf, 1984; Myers, 1984) and taxation (DeAngelo and Masulis, 1980; Bradley et al., 1984) with the value of the firm. . Graham (1999) posits that taxations do in fact affect corporate financing decisions but the magnitude of such an effect is mostly not large.

Mackie-Mason (1990) as stated by Joshua (2008) concludes that changes-in the marginal tax rate for any firm should affect its choices between equity and debt

\section{Ownership structure and capital structure}

The link between ownership structure and capital structure is an essential one as it supports the relationship between corporate governance and firm performance. External block holders have solid incentives to reduce managerial opportunism (Shleifer and Vishny, 1986) and they may wish to use debt as a governance mechanism to control management's consumption of perquisites (Grossman and Hart, 1982). If external block holders monitor management effectively, managers may not be able to adjust debt to their own interests as freely as if such investors did not exist (Brailsford et al., 2002). In that case firms with enormous exterior block holdings are expected to have higher debt ratios at least up to the point where the risk of bankruptcy may prompt them to lower debt. Family firms may also use higher debt levels to the extent that they are perceived to be less risky by debt holders (Anderson et al., 2003).

Friend and Lang (1988) had a positive relationship between enormous external ownership and debt. The same authors also find a negative relation between leverage and interior share 
ownership same with the view that managerial block holders select lower debt to protect their non-diversifiable human capital and wealth invested in the firm. Brailsford et al. (2002) studies also show a positive relation between external block holders and debt. However they find that the relationship between managerial share ownership and leverage is non-linear. By low levels of managerial ownership, agency conflicts compel the use of more debt but as managers become engrained at high levels of managerial ownership they try to find a way to reduce their risks and they use less debt. Anderson and Reeb (2003b) find that insider ownership by managers or families has no effect on leverage while King and Santor (2008) shows that both family and financially controlled firms carry more debt in their capital structure.

\section{The Nigerian Cement Industry}

The cement industry in Nigeria has experienced immense growth over the past few years. With a population of over 140 million people and a growth rate of approximately $3 \%$ yearly, the demand for and consumption of cement is expected to increase. Government however remains the largest consumer of cement in the country with an estimated $50 \%$ of total consumption. The frequency of roads and bridge reconstruction as well as rehabilitation of social infrastructure emphasises government's continued patronage of the industry but also widens the demand-supply gab which currently exist. The Nigerian cement industry has the potential to contribute to the larger economy in several ways. First, by virtue of its nature, the industry is a labour intensive and is therefore a major employer of labour both skilled and unskilled. The industry also has a significant contribution to the country's Gross Domestic Product (GDP) and is a source of foreign direct investment. Though the construction, renovation and rehabilitation of major roads, bridges, networks and public infrastructure, the cement industry plays a major role in overall economic development and enhancement of social welfare.

The Nigerian cement industry was one of the earliest import-substitution industries in the country. The history of the cement production in Nigeria dates back to 1957. Initially three cement plants were commissioned by the northern, eastern and mid-western regional government. Subsequently, other companies such as Ashaka cement, BENUE cement company (BCC), west African Portland Cement Company (WAPCO) and Cement Company of Northern Nigerian (CCNN) were established. Today, there is several cement plants located in various parts of the country. Some of the notable companies include: West African Portland Cement Company Plc (WAPCO), Ashaka Cement Plc, Benue Cement Company Plc (BCC), Cement Company of Northern Nigeria (CCNN), Dangote Industries Limited, Nigerian Cement Company Limited, Edo Cement Company Limited, and Calabar Cement Company Limited. One of the major characteristics of the cement industry in Nigeria is the problem of demand vs. supply inequality. Since inception, available supply has not been able to meet the ever growing demand for cement. Even in 1980's, during the economic recession which witnessed a decline in the demand for cement, these supply gabs were still very much evident (DLM Research, 2014).

The cement industry is crucial to the provision of adequate and affordable houses for the various strata of the Nigerian society. It is therefore necessary to evaluate/assess its well-being in the face of current happenings in the economy; like increased competition from imported brands, privatization, the perennial 'marginalization' of the manufacturing sector by lenders, inflation and all sorts (Benjamin, 2004). 


\section{Empirical Review of Related Literature}

Capital structures are studied by quite number researchers within and across the world. Evidence shows that findings were obtained from the studies as regard to capital structure and financial performance of firms, industry as well as the economy as whole.

Earlier among the studies reviewed are the work of Margatitis and Psillaki (2009), where they used quartile regression methods and found out that the nature of relationship between leverage ratios and firm performance is positive and significant. Their research used long term and short term leverages to proxy leverage ratios and firm characteristics as control variables. Also, Adeyemi and Abor (2011) examined the relationship between capital structure and firms value. Their study used chi-square to measure longitudinal data. Their findings reveal significant positive relationship between the choice of capital structure and market value.

Besides, Awunyo and Badu (2012), study listed banks to examined the impact of capital structures on performance of banks. The study employs both market and accounting performance measure and leverage ratios, firm size, age and board size are regress. Their finding shows that listed banks are highly geared and negatively related to bank performance. This may be attributed to the researchers over dependence on short term debt due to high level of lending rate and low level of bond market activities. Similarly, Antwi and Zhao (2012) used cross-sectional data on 34 quoted firms in Ghana and their result shows that component of capital structure (i.e., equity capital) is important to the firm value. Long term debt as the key determinant of firms value, is discovered to have more impact than equity capital.

Babalola (2012) assessed the impact of capital structure on firm performance using 10 firms over the period of 10 spanning from 2001-2009. He measures performance in a quadratic function, whereby performance forms the non-linear function of capital structure, as proxy by leverage ratio. The finding supports trade off theory in another dimension. In another study conducted by Ganiyu and Babalola (2012), where performance is measured by return on Assets and corporate governance variables to find their effect on capital structure and the result indicate that corporate governance has impact on company's financial decision.

Muritala (2012), in his effort to analyse capital structure on firms' performance in Nigeria, used unit root test and found that all variables used were non-stationary at all level. The study proposes that negative relationship exist between capital structure and firm performance. Data analysed using panel least square confirm that asset turnover, age, tangibility and firm size are positively related to firm's financial performance.

In Sri Lanka Leon (2013) and Nirajini and Priya (2013) study the effect of capital structure of firms performance. The former examined the listed manufacturing firms, while the later study trading companies listed at the stock exchange. Both studies used 5 years data from financial reports and accounts of the selected companies in the respective industries. Leon employs ROE and ROA to measure performance, while Nirajini and Priya used Gross profit, net profit, ROCE, ROE and ROA as performance measures. Both results indicate significant relationship between performance and leverage.

The result of empirical literature on the relationship between capital structure and firm performance are conflicting, as such necessitate further research despite those conducted in Nigeria and across, as little need to be done to improve the researches to suit the Nigerian context given the differences in technological advancement, level of economic growth, politics, laws, leadership style and level of awareness. Hence, this study covers the period spanning 2010-2014. 


\section{Theoretical Framework}

Many scholars have advanced numerous explanations which serve as theoretical backing on the concept on capital structure. For the purpose of this research, the paper tends to look at the most commonly used theories on capital structure. Besides this theories are not exhaustive.

\section{Modigiliani-Miller Theory}

The Modigliani-Miller theorem (of Franco Modigliani, Merton Miller) forms the basis for contemporary thinking on capital structure in 1958. The basic theorem states that, under a certain market price process (the classical random walk), in the absence of taxes, bankruptcy costs, and asymmetric information, and in an efficient market, the value of a firm is unaffected by how that firm is financed (Myers, 2001). It does not matter if the firm's capital is raised by issuing stock or selling debt. It does not matter what the firm's dividend policy is. Therefore, the Modigliani-Miller theorem is mostly referred to as the capital structure irrelevance principle.

The theorem was originally proven under the assumption of no taxes. According to Frank and Goyal, (2008), it is made up of two propositions which can also be extended to a situation with taxes. Consider two firms which are identical except for their financial structures. The first (Firm $U$ ) is unlevered that is, it is financed by equity only. The other (Firm L) is levered: it is financed partly by equity, and partly by debt. The Modigliani-Miller theorem states that the value of the two firms is the same.

\section{Trade-off Theory}

Kim (1978) studies showed that the choice of capital structure matters in influencing performance. The trade-off theory refers to the idea that a company chooses how much debt finance and how much equity finance to use by balancing the costs and benefits (Margaritis and Psillaki, 2009). Trade-off theory gives chance for the existence of bankruptcy cost. It states that there is an advantage to financing with debt (namely, the tax benefit) and that there is a cost of financing with debt (the bankruptcy costs and the financial distress costs of debt) (Kraus and Litzenberger, 1973). Miller (1977) argues that these costs do exist indeed, but they seem inexplicably small relative to tax savings as they are supposedly balanced. However, to Myers (1984), the marginal benefit further increases as debt declines, and as debt increases, while the marginal cost increases, so that a firm that is optimizing its overall value will focus on this trade-off when choosing how much debt and equity to use for financing. Empirically, this theory may explain differences in D/E ratios between industries, but it doesn't explain differences within the same industry (Margaritis and Psillaki, 2009). As such it usage under this study becomes imperative as the paper focus on trend analysis of cement industry financial performance.

\section{Pecking Order Theory}

In the theory of firm's capital structure and financing decisions, the pecking order was first proposed by Donaldson in 1961 and it was improved by Myers and Majluf (1984). It states that companies place in order of preference their sources of financing (from internal financing to equity) according to the norm of least effort, or of least resistance, preferring to raise equity as the last alternative means financing decision. Therefore, internal funds are used first, and when that is exhausted, debt is issued, and when it is not functional to issue any more debt, equity is issued (Myers, 2001).

Pecking Order theory attempts to capture the costs of lopsided information. It states that companies place in order their sources of financing from what it has at hand, when that becomes exhausted, then proceed to debt issue, when this seem work no longer, finally equity 
becomes the last option. This is in accordance with the law of least effort, or of least resistance. This theory preserves that firms abide by the chain of command of financing sources and prefer internal financing when accessible, and debt is preferred over equity if external financing is necessary. As a result, the form of debt a firm decide on act as a sign of its need for exterior finance. The pecking order theory is dispersed by Myers (1984), when he argues that equity is a less preferred means to raise capital because when managers issue new equity, investors have confidence that managers think that the firm is overestimated and as such managers are captivating the benefit of this over-estimation. Thus, investors tend to place a lower price to the new equity issuance.

\section{Agency Theory}

This is a theory about the relationship between the principal (owner/shareholders) and the agent of the principal (employees/managers). This recommends that the firm can be regarded as a link of contracts between resource holders. An agency relationship ascends whenever one or more individual, called principals, hire one or more other individuals, called agents, to perform some service and then delegate decision-making authority to the agents (Margaritis and Psillaki, 2009). The agency theory perception was originally advanced by Berle and Means (1932), who argued that due to a continuous dilution of equity ownership of large corporations, ownership and control become more separated. This situation gives professional managers an opportunity to pursue their interest instead of that of shareholders (Jensen,1986) as cited in Salawu (2009). In theory, shareholders are known to be the only owners of a company, and the job of its directors is purely to safeguard and ensure shareholders' interests are maximized.

The issue here is that the interest of the principal and the agent are never precisely the same, hence the agent, who is the decision-making part, tries always to pursue his own interests in place of those of the principal. The main problem faced by shareholders is to ensure that managers will return excess cash flow to them (e.g. through dividend payouts), instead of having it invested in unprofitable projects (Jensen and Meckling, 1976). Muritala (2012), assert that, if the principal wants to make sure that the agent acts in his interests he must undertake some Agency costs (e.g. the cost of monitoring managers). As such the more the principals want to control the conduct of manager decisions the higher their agency costs will be. Yet, modern research has revealed that capital structure can somewhat cope with the principalagent problem without substantially increasing agency costs, but simply by trading off equity for debt (Pinegar and Wilbricht, 1989; Muritala, 2012).

Lubatkin and Chatterjee, (1994), argue that firms can discipline managers to run businesses more efficiently by increasing their debt to equity ratio. Debt creation ensures contractually that managers will return excess cash flow to investors instead of investing it in projects with negative NPVs (Onaolapo and Kajola, 2010). This is caused by high degrees of control demand high interest expenses, which force managers to focus only on those activities necessary to ensure that the financial obligations of the firm are met. Hence, by having less cash flow available, managers of highly leveraged firms see their ability of using the firm's resources for discretionary- and often useless-spending, dramatically reduced.

The theory underpinning this research work is the trade-off theory. The theory is profit motivated theory. Trade off theory explains that tax shield debt has effect on firm profitability and shows that firm can get optimum capital structure. The theory further shows that, the form of debt capital could equally have effect on firm's performance. 


\section{Research Methodology}

The research design employed in this study is ex post facto research design. Four (4) out of the seven (7) companies in Nigerian cement industry were selected as sample of the study. Data were collected from Annual Reports and Accounts of the sampled companies from the Nigerian Stock Exchange for the period of five (5) years i.e. 010 - 2014. The data were analysed using STATA software version 12.00 where summary of descriptive statistics, correlation and multiple regressions results were obtained and analysed to determine the impact of capital structure on firm financial performance in the listed Nigerian cement companies. This study uses two variables; dependent and explanatory variables. The dependent variable is the most usual accounting performance ratio; ROE is the measure of ratio of earnings before interest and tax to ordinary shareholders capital ( Anwuyo and Badu, 2013; Muritala, 2012 and Oladeji \& Olokoyo, 2014). It explains how well management is able to manage the equity invested by shareholders (Saidu, 2014).

Explanatory variables include both the independent and control variables adopted for the study. Independent variable for the study is leverage or debt commonly used in the research work. It is represented by debt to total assets ratio, divided into two; Long term debt to total asset; and Short term debt to total asset ratios as used by (Margatitis \& Psillaki, 2009; Anwuyo \& Badu, 2013; Muritala, 2012; Antwi, Mills \& Zhao; and Oladeji \& Olokoyo, 2014). It is the ratio of total debt to the net assets of the companies. Firm size is the most commonly investigated control variable suggested to affect firm performance (Garko, 2012). It is measured as the log of total assets as used by (Garko, 2012 Muritla, 2012 and Anwuyo and Badu 2013).

In a bid to examine the impact of capital structure on firm's performance, we specify a model in line with the traditional theory of capital structure. The model is designed to accommodate ordinary least square (OLS) regression. As such, we adopt the capital structure model that states that firms' performance depends on capital structure and some control variables that is two independent variable and one control variable. Thus, following (Muritala, 2012; Ogebe et al, 2013; Oladeji and Olokoyo, 2014 and Saidu, 2014);

Performance $=\mathrm{f}($ leverage, size $)+\varepsilon \mathrm{i}$

ROA it $=\beta 0+\beta 1 \mathrm{LTD} / \mathrm{TA}$ it $+\beta 2 \mathrm{STD} / \mathrm{TA}$ it $+\beta 3 \mathrm{SIZE}+\varepsilon$ it

ROE it $=\beta 0+\beta 1 \mathrm{LTD} / \mathrm{TA}$ it $+\beta 2 \mathrm{STD} / \mathrm{TA}$ it $+\beta 3$ SIZE $+\varepsilon i t$

The above model shows that the firm's performance relies on capital structure and size of the firm.

Where:

ROE $=$ Return on asset

Size $=$ Firm size or size of the firm

Leverage $=$ total debt $/$ total asset

LTD/TA = long term debt to total assets

STD $/ \mathrm{TA}=$ short term debt to total assets

SIZE $=$ Log of the total assets

$\varepsilon t=$ the error term

\section{RESULTS AND DISCUSSIONS}

This section presents, analyse, interprets and discuss the result obtained from the data generated from annual report and accounts of the sampled cement companies for the period of the study. The data was analysed using descriptive statistics, correlation matrix of the dependent and explanatory variables and regression analysis. The descriptive statistics 
explains the various statistics such as mean, standard deviation and long term debt structure of the cement companies and Correlation matrix was employ to examine the relationship between the explanatory variable while regression coefficients with the purpose of testing the relationship between variables of the study. Table 1 provides such statistics.

Table 1: Descriptive Statistics of the Variables

\begin{tabular}{|c|c|c|c|c|c|}
\hline Variable | & Obs & Mean & Std. Dev. & Min & $\operatorname{Max}$ \\
\hline roa & 20 & .0124255 & .0057012 & .0049652 & .0199005 \\
\hline roe & 20 & .2211664 & .1277463 & .0598853 & .5040225 \\
\hline tita & 20 & .3850627 & .1365481 & .1562515 & .6325405 \\
\hline 1 t ta & 20 & .169889 & .0857874 & .069694 & .419614 \\
\hline stlta | & 20 & .2150385 & .1143803 & .019451 & .490122 \\
\hline siz & 20 & 8.731998 & .9228414 & 7.449094 & 10.19811 \\
\hline
\end{tabular}

Source: Generated by the Researchers from the Annual Reports and Accounts of the sampled companies using Stata (Version 12)

Table 1 reveals that the Return on Assets (ROA) of the companies in the cement industry over the five year period ranged from $0.50 \%$ to a maximum of $1.99 \%$ and with average values of the dependent of $1.24 \%$ and the standard deviation is 0.0057012 indicating lack of substantial variation. Other variables which are independent in the table also indicate some level of variability. On the overall Total Liability to Total Assets (TLTA) has the highest standard deviation with about 1365481 and Return on Assets (ROA) has the lowest standard deviation account for only .0057012 . These indicate that the long term debt and short term debt occupy $17 \%$ and $22 \%$ of the total assets.

In order to examine the level of relationship between the dependent and independent variables, correlation matrix is used. Variance Inflation Factor (VIF) test is carried out also to find out whether or not multi-collinearity exists as a result of the relationship between the variables. The correlation matrix in Table 2 provides some insights into which of the independent variables are related to the Return on Assets (ROA) (i.e., the dependent variable).

Table 2: Correlation Matrix of the Variables

\begin{tabular}{r|rrrrrr} 
& roa & roe & tlta & 1tlta & stlta & size \\
roa | & 1.0000 & & & & \\
roe | & 0.0917 & 1.0000 & & & & \\
thta | & 0.5025 & 0.0578 & 1.0000 & & & \\
lttta | & 0.3050 & 0.1713 & 0.5515 & 1.0000 & & \\
stlta | & 0.3706 & -0.0593 & 0.7800 & -0.0918 & 1.0000 & \\
size | & 0.3439 & 0.3316 & 0.2218 & -0.1641 & 0.3859 & 1.0000
\end{tabular}

Source: Generated by the Researcher from the Annual Reports and Accounts of the sampled companies using Stata (Version 12)

From the above table, the values are on diagonal all 1.0000 which indicate that each variable is perfectly correlated with itself. All the independent variables are positively correlated with Return on Assets (ROA). The positivity nature of the correlations implies that as the rate Return on Equity (ROE) with a correlation coefficient value of 0.0917 , Total Liability to Total Assets (TLTA) with a correlation coefficient value of 0.5025 , Long Term Liability to Total Assets (LTLTA) with a correlation coefficient value of 0.3050 and Short Term Liability to Total Assets (STLTA) with a correlation coefficient value of 0.3706 as well as size with a correlation coefficient value of 0.3439 increases, the Return on Assets (ROA) of the companies under study 
also increases which means that the relationship is not strong (i.e., weak). However, the highest correlation coefficient from the table is $78 \%$ which indicates that there is no multicolinearity between the variable. As Brooks (2000), cited in Cathode (2002) opined that multicolinearity is present only if the correlation coefficient is $80 \%$ or above.

Table 3.1: Regression Result

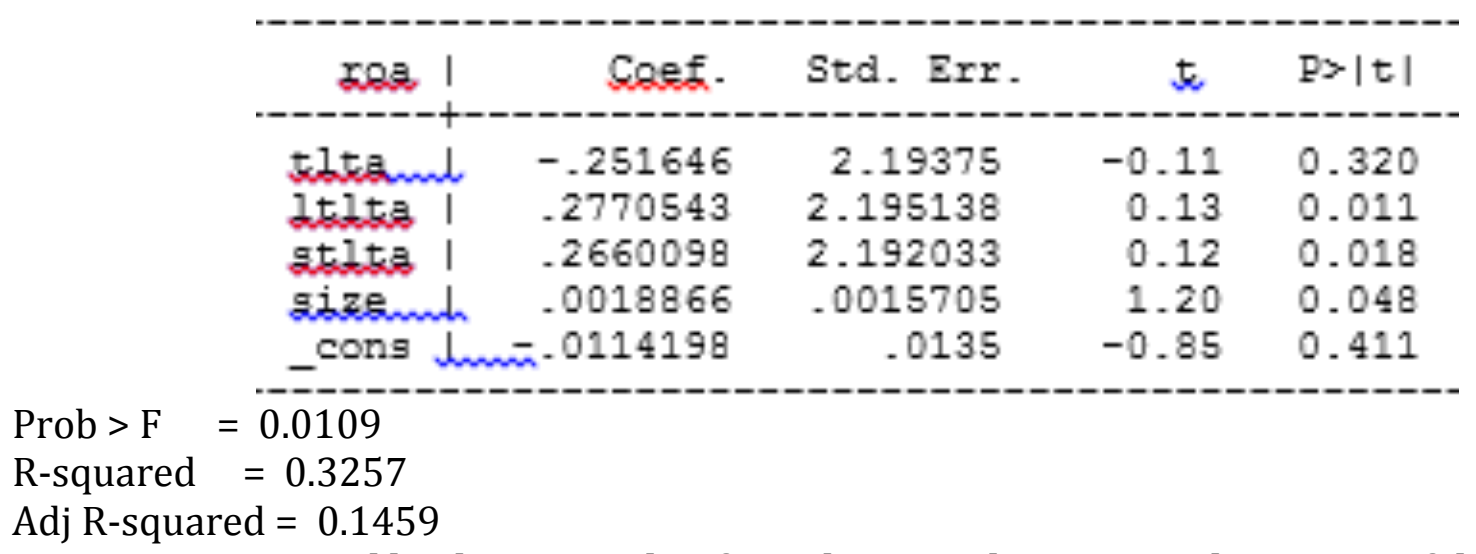

Source: Generated by the Researcher from the Annual Reports and Accounts of the sampled companies using Stata (Version 12)

Table 3.1 presents the regression results of the 1st model equation of the dependent variable (ROA) and independents as well as explanatory variables (total liability to total assets, long term liability to total assets, short term liability to total assets and size). The coefficient of "Rsquared" shows $32.57 \%$ which indicate that the variables used in the model accounts for about $32.57 \%$ variation on ROA as the dependent variable, whereas the remaining of the variation accounts for the outcome of other variables which were not considered by this model. However, the whole probability is positively significant at $10 \%$. As such, the 1 st model equation can be inscribed as: ROA $=-.0114198+.2770543 \beta 1+.2660098 \beta 2+.0018866 \beta 3+\varepsilon$

In assessing the 1st model of the regression equation, the results shows that, the relationship between ROA and is positive and significant, this can be justified with the " $t$ " value of 0.13 and $P>|t| 0.011$. Similarly the result of the coefficient 0.2770543 is positive, which means that an increase in LTLTA will lead to increase in financial performance of cement companies. This infers that, LTLTA has a positive relationship with ROA. So also the relationship between ROA and STLTA is positive but not significant, which is can be justified with positive " $t$ " value of 0.12 and $P>|t| 0.018$ which also has a positive coefficient of 0.2660098 , this implies that, STLTA has a positive and statistically significant relationship with ROA. Meaning that both long and short term liability to total assets also increased financial performance of the cement companies. The result is consistent with some empirical findings such as Magatitis \& Pssillaki (2009); Suleiman (2013) and Goyal (2013). The finding also conflict with that of Saidu (2014) who maintained that capital structure in financial performance of firms' pension industry has a negative impact on their performances.

Finally, the result of size indicate positive with a significant relationship at $5 \%$ level of significance on financial performance of the sampled cement companies with a coefficient value of 0.0018866 and $\mathrm{P}>|\mathrm{t}|$ 0.048, which indicate that the size of the company has something do with it financial performance as used by Garko (2012). 
Table 3.2: Regression Result

\begin{tabular}{|c|c|c|c|c|}
\hline xoe I & Caef. & Std. Err. & t & $P>|t|$ \\
\hline trltand & $\begin{array}{r}-.09314 \\
461114\end{array}$ & $\begin{array}{r}.79852 \\
8313\end{array}$ & -1.01 & 0.031 \\
\hline stlta | & .8143 & .75799 & 1.00 & 0.033 \\
\hline gijzemm & .07759 & .037083 & 2.09 & 0.054 \\
\hline _cons I & -.45193 & .31876 & -1.42 & 0.177 \\
\hline
\end{tabular}

Prob $>\mathrm{F}=0.0017$

R-squared $=0.2512$

Adj R-squared $=0.1725$

Source: Generated by the Researcher from the Annual Reports and Accounts of the sampled companies using Stata (Version 12)

Table 3.2 presents the regression results of the 2 nd model equation of the dependent variable (ROE) and independents as well as explanatory variables (long term liability to total assets, short term liability to total assets and size). The coefficient of "R-squared" shows 25.12\% which indicate that the variables used in the model accounts for about $25.12 \%$ variation on ROE as the dependent variable, whereas the remaining of the variation accounts for the outcome of other variables which were not considered by this model. It is also positively significant at $10 \%$. As such, the 2 nd model equation can be inscribed as: $\mathrm{ROE}=-.45193+$ $.46114 \beta 1+.8143 \beta 2+.077597 \beta 3+\varepsilon$

In evaluating the 2 nd model of the regression equation, shows that, the relationship between ROE and is positive and significant, this can be justified with the " $t$ " value of 1.01 and $P>|t|$ 0.028 . Similarly the result of the coefficient 0.46114 is positive, which also means that an increase in LTLTA result to increase in financial performance of cement companies. This infers that, LTLTA has a positive relationship with ROE. So also the relationship between ROE and STLTA is positive and statistically significant, justifiable with positive " $t$ " value of 1.00 and $P>|t|$ 0.033 which also has a positive coefficient of 0.8143 , which also implies that, STLTA has a positive and statistically significant at 3\% level of significance with ROE. Meaning that both long and short term liability to total assets also increased financial performance of the cement companies. The result is consistent with Modigliani and Miller (1958) capital structure irrelevancy theory, which however goes against agency theory that debt is negatively impact on performance. That is to say leverage affects firm performance positively. The findings are contrary to empirical findings of Saidu (2014); Awuyo-Victor \& Badu (2012); Suleiman (2013) and in line with Safar, Assif \& Arshad (2013).

Lastly, the result of size as a control variable point out to be positive with a significant relationship at 5\% level of significance on financial performance of the sampled cement companies with a coefficient value of 0.077597 and $P>|t| 0.054$, which indicate that the bigger the size of the company the higher the financial performance.

However, using both the two models result to significant impact at significance level of $10 \%$ for explanatory variables on the dependent variables (i.e., ROA \& ROE) but based on the findings ROE is more preferable than ROA. As such the study adopts ROE as a measure of financial performance of cement companies. 


\section{CONCLUSIONS AND RECOMMENDATIONS}

The paper examines the impact of capital structure on firm's financial performance in the Nigerian cement industry. From the result of the findings of the study, it can be inferred that financial performance increases capital structures as thus;

1. There is statistically significant relationship between long term liability and return on assets.

2. There is significant causal relationship between short term liability and return on assets.

3. There is statistically significant causal relationship between return on equity and long term liability in the Nigerian cement industry.

4. There is also statistically significant relationship between long term liability and return on equity.

Based on the findings the paper recommends that cement companies should encourage the use of long term debt in there capital structure since it has positive impact on their financial performance and managers in the cement industry should ensure both long and short term debt becomes relevant in influencing their performance as measured by return on assets and equity by making proper utilization of the loan capital.

\section{References}

Adeyimi, S. B. \& Obor, C. S. (2011). Perceived relationship between corporate capital structure and firm value in Nigeria, International Journal of Business and Social Sciences, 2(9):131-143.

Anderson, R. C., Mansi, S. A. \& Reeb D. M. (2003). Founding family ownership and the agency cost of debt. Journal of Financial Economics, 68: 263-285.

Antwi, S. \& Zhao, X. (2012). Capital structure and firm value: empirical evidence from Ghana. International Journal of Business and Social Science Vol. 3 (22) [Special Issue - November 2012] 103.

Awunyo-Vitor, D. \& Badu, J. (2012). Capital structure and performance of listed banks in Ghana. Global Journal of Human Social Science (USA), 12 (5) Version I.

Babalola, A. Y. (2012). Effects of optimal capital structure on firm performance. Journal of Emerging Trend in Economics and Management Sciences 3(2): 131-133.

Barclay, M. \& Smith, C. (2005). Capital structure puzzle: The evidence Revised. Journal of Applied Corporate Finance, 17(1):8-17

Berger, A. N. \& Bonaccorsi, E. (2006). Capital structure and firm performance: A new approach to testing agency theory and an application to the banking industry. Journal of Banking and Finance 30: 1065-1102.

Bradley, M., Jarrell, G. \& Kim, E. H. (1984). On the existence of an optimal capital structure: theory and evidence. Journal of Finance 39, 857-878.

Brailsford, T. J., Oliver, B.R. \& Pua, S.L. (2002). On the relation between ownership structure and capital structure. Accounting and Finance 42:1-26.

Brealey, R. A. \& Myers, S. C. (2003). Principles of Corporate Finance, New York, and McGraw - Hill.

Brockington, R. (1990). Financial Management, 1992 Edition, ELBS, London.

DeAngelo, H. \& Masulis, R. (1980). Optimal capital structure under corporate and personal taxation. Journal of Financial Economics 8(1), 3-29.

Friend, I. and L. Lang (1988). An empirical test of the impact of managerial self-interest on corporate capital structure. Journal of Finance, 43 (2): 271-281.

Frank, Z., M. and Gayol, V. K. (2003). Testing the pecking-order theory of capital structure. Journal of Financial Economics, 67 (2003): 217-248. 
Garko, J. S. (2012). Ownership structure and financial performance of listed Nigerian consumer Goods companies. Bayero Journal of Accounting Research Special Edition, Vol. Pp. 42-52

Ganiyu, Y. O. \& Abiodun, Y. B. (2012). The impact of corporate governance on capital structure decision in Nigerian firm. Research Journal in Organisational Psychology and Educational Studies. Vol. 1(2): Pp. $121-128$.

Graham, J. (1999). How big are the tax benefits of debt? Journal of Finance 55:1901-1941.

Graham, J. \& Harvey, C. (2001): The theory and practice of corporate finance: evidence from the field, Journal of Financial Economics, 60: 187-243.

Grossman, S. J. \& Hart, O. (1982). Corporate financial structure and managerial incentives. In McCall, J. (ed.) the Economics of Information and Uncertainty (Chicago: University of Chicago Press).

Gropp, R. \& Heider, F. (2009). The determinant of bank capital structure. European central Working Paper.

Harris, M. and Raviv, A. (1988). Corporate Control Contests and Capital Structure. Journal

of Financial Economics 20, 55-86.

Harris, M. and Raviv, A. (1990). Capital structure and the informational role of debt. Journal of Finance, 45 (2): 321-49.

Jensen, M. and Meckling, W. (1976): Theory of the firm: managerial behavior, agency costs and ownership structure. Journal of Financial Economics, 3:305-60.

Jensen, M. (1986). Agency costs of free cash flow, corporate finance, and takeovers. American Economic Review, 76: 323-329.

Kochhar, R. (1997). Strategic assets, capital structure, and firm performance. Journal of Financial and Strategic Decisions, 10 (3): pp.23-36.

Kraus, A. \& Litzenberger R. (1982). A State-Preference model of optimal financial Leverage, Journal of Finance, 27: $199-22$

King, M. R. \& Santor, E. (2008). Family values: ownership structure, performance and CAPITAL Structure of Canadian firms. Journal of Banking and Finance, 32: 2423- 2432.

Kim, E.H. (1978). A mean-variance theory of optimal structure and corporate debt capacity". Journal of Finance, 33(1): 45-63.

Leon, J. S. (2013). The impact of capital structure on financial performance of listed manufacturing firm in SriLeon. Global journal of common wealth Management perspective, 2(5): 55-62.

Lubatkin, M. \& Chatterjee, S. (1994). Extending modern portfolio theory into the domain of corporate diversification: Does it apply? Academy of Management Journal, Vol. 37:109-36.

Mackie-Mason, J. K. (1990). Do firms care who provides their financing? In Hubbard, R.G., ed., asymmetric information, corporate finance, and Investment. A national bureau of Economic Research Project Report, Chicago and London: University of Chicago Press, 63-104.

Margaritis, D. \& Psillaki, M. (2009). Capital structure, equity ownership and firm performance, Dept. of Finance, Faculty of Finance, AUT.

McGuire, I., Schneeweis, T. \& Hill. T. (1986). Perception of firm quality. A cause result of firm performance. Journal of management, Vol. 16(1): Pp. 167-180.

Modigliani, F. \& Miller, M. (1958). The cost of capital, corporate finance and the theory of Investment. American Economic Review, Vol. 48, pp. 261-297.

Miller, M. H. (1977). Debt and Taxes. Journal of Finance Vol. 32 (2): 261- 275.

Muritala, T, (2012). An Empirical Analysis of Capital Structure on Firms' Performance in Nigeria International Journal of Advances in Management and Economics. Vol.1 (5): 116- 124

Myers, S. C. (1984). The capital structure puzzle. Journal of Finance, Vol. 34, pp. 575 - 592.

Myers, S. C. (1993) still searching for optimal capital structure. Journal of Applied Corporate Finance, Vol. 6 (1): 4 -14 . 
Myres, S. C. (2001). Capital structure. The journal of economic Perspectives, 15 (2): 81-102.

Myers, S. C. \& Majluf, N. S. (1984). Corporate financing and investment decision when Firms have Information that Investors do not have. Journal of Financial Economics, Vol. 13:187-221.

Nirajini,A \& Priya,K. B. (2013). Impact of capital structure on financial performance of listed trading companies in Sri Lanka. International Journal of Scientific and Research Publications, Vol. 3(5): ISSN 2250-3153.

Ogebe, O., Ogebe. J. \& Alewi, K. (2013). The impact of capital structure on firm's performance in Nigeria. MPRA Paper No. 46173

Olokoyo, F. O. (2013): Capital Structure and Corporate Performance of Nigerian Quoted Firms: A Panel Data Approach. African Development Review. Vol. 25 (3), Pp. 358-369.

Onaolapo, A. A. \& Kajola, S. O. (2010): “Capital Structure and Firm Performance:

Evidence from Nigeria", European Journal of Economics, Finance and Administrative Sciences, Issue, 25:70- 82.

Oladeji, T. \& Olokoyo, F. O. (2014). An empirical analysis of capital structure on performance of Firms in the Petroleum Industry in Nigeria. A Conference Paper at Dept. of Finance, Faculty of Finance, AUT.

Pinegar, M. and Wilbricht, L. (1989). What Managers Think of Capital Structure Theory: A Survey, Financial Management, Pp. 82-91.

Saidu, S. (2014). Capital Structure and Financial Performance of Firms' in the Nigerian Pension Industry. An Unpublished Dissertation Submitted to School of Postgraduate,

Bayero University Kano in Fulfilment of the Requirement of Masters in Accounting.

Salawu, R. O. (2009). The Effect of Capital Structure on Profitability: An Empirical Analysis of listed firms in Nigeria. The International Journal of Business and Finance Research; Vol. 3 (2). Pp 16-18.

Sulaiman, M.A. Al-Sakran, (2001). Leverage Determinants in the Absence of Corporate Tax System: The Case of Non-Financial Publicly Traded Corporations in Saudi Arabia Managerial Finance Vol. (27): Pp. 261 - 275.

Sulaiman, A. (2001). Capital Structure's Effect on Firms Performance; Evidence from listed Saudi Companies, M.Sc., Theses at St. Mary's University.

Shleifer, A. and Vishny, R. W. (1986). Large shareholders and corporate control. Journal of Political Economy. Vol. 94, Pp. 461-488. 